\title{
DETERMINING THE CHARACTERISTICS OF DIRECT RUNOFF FROM REAL RAIN USING GIS ENVIRONMENT STANOVENIE CHARAKTERISTÍK PRIAMEHO ODTOKU Z REÁLNEHO DAŽĎA S VYUŽITÍM PROSTREDIA GIS
}

\author{
Karol ŠINKA, Tatiana KALETOVÁ \\ Slovak University of Agriculture in Nitra, Slovak Republic
}

\begin{abstract}
The selected SCS-CN method is used worldwide and adapted to the conditions of Slovakia. GIS environment provides an opportunity to simulate changes in land use, and then to calculate the total volume of water from the river and peak water flow in the river bed of the stream. The simulation was done for two rainfall events, $72 \mathrm{~mm}$ and $42.6 \mathrm{~mm}$, which were measured in precipitation station in Jelenec (a village situated next to the area of interest). The calculation was made for 4 possible scenarios current land use, forest, arable land and grassland and pasture. Culmination discharge and time of outflow from rainfall $72 \mathrm{~mm}$ for current land use were calculated using the NRCS method. The calculation of water runoff volume showed that similar values were measured for the rainfall of $72 \mathrm{~mm}$ and rainfall $42.6 \mathrm{~mm}$ in case of AMC-III. The highest values of water runoff volume were marked in the case of arable land in all calculations, the lowest one for forest. Comparison of designed stream cross section and calculated culmination discharge allowed us to determine the point of outflow from the river bed of the Drevenica stream.
\end{abstract}

Keywords: direct runoff, discharge, Drevenica, SCS-CN method, flood

Nowadays, professional but also general public interferes with the issue of dealing with extreme situations related to water in landscape, either with its excess or lack. Whether in landscape one or the other extreme occurs, it always intervenes adversely in activities and lives of people. While drought comes slowly and gradually, flood may occur within a few hours or minutes in case of an extreme rainfall. Flood protection has become a common theme for the EU institutions. The Directive 2007/60/EC of the European Parliament and of the Council from 23 October 2007 on the assessment and management of flood risks was implemented. The Directive was implemented into the Act No. 7/2007 Coll. (Slovak Republic), which defines flood risk as a combination of the probability of flooding and its potential adverse effects on human health, environment, cultural heritage, and economic activity.

Modern flood control is built on four pillars:

1. Flood protection in landscape - built-up areas and activity in landscape, flood protection organization, risk analysis, and modelling of floods.

2. Technical flood protection - weirs, polders, reservoirs (tanks), mobile devices for the protection of landscape, maintenance of riverbeds.

3. Retention of water in landscape - retardation of runoff by modification of riverbeds, sewer networks solution, increase in infiltration, surface roughness and retention, crop rotation, tillage methods, etc.

4. Human factor - really responsible people, staff training, regular inspections of landscape and establishment of goals after the critical state, science and research, legislation, technical standards, support organizations and financial conditions for preventive action (Tupy et al., 2011).

Considering the spatial and temporal variability of landscape and absence of sufficient measurement and data from partial localities, it is very difficult to solve flooding problems on the direct monitoring; therefore, different models are used to simulate rainfall-runoff processes in country (FRIER, SMODERP, TOPMODEL...). The greater the complexity of the model, the more input data is required. In conditions of Slovakia, it is often difficult to obtain representative data from small catchments in which the highest damage is caused at landscape and property of people.

The months of May and June 2010 marked above standard rainfalls and during those months the rivers overflowed. Damages caused on people's property were recorded throughout the whole Slovakia. The Drevenica catchment was no exception.

The aim of this paper is to show the change of the volume of runoff from the real rainfall in the case of various land uses using SCS-CN method in GIS environment in the subcatchment Drevenica (from its stream to its confluence with the Jelenský creek). We have expanded the problem of determination the time of runoff concentration from the subcatchment and the location of point of outflow from the riverbed for selected rainfall event and present landscape structure.

\section{Material and methods}

The area of interest is subcatchment of the Drevenica stream to the confluence with the Jelenský creek with an area of $3,635.823$ ha. The area of interest is located in the southwestern Slovakia in Nitra region, on the border of Nitra and Zlate Moravce districts. The Drevenica stream flows through the villages Kostolany pod Tríbečom, Ladice and Neverice within the area of interest. 


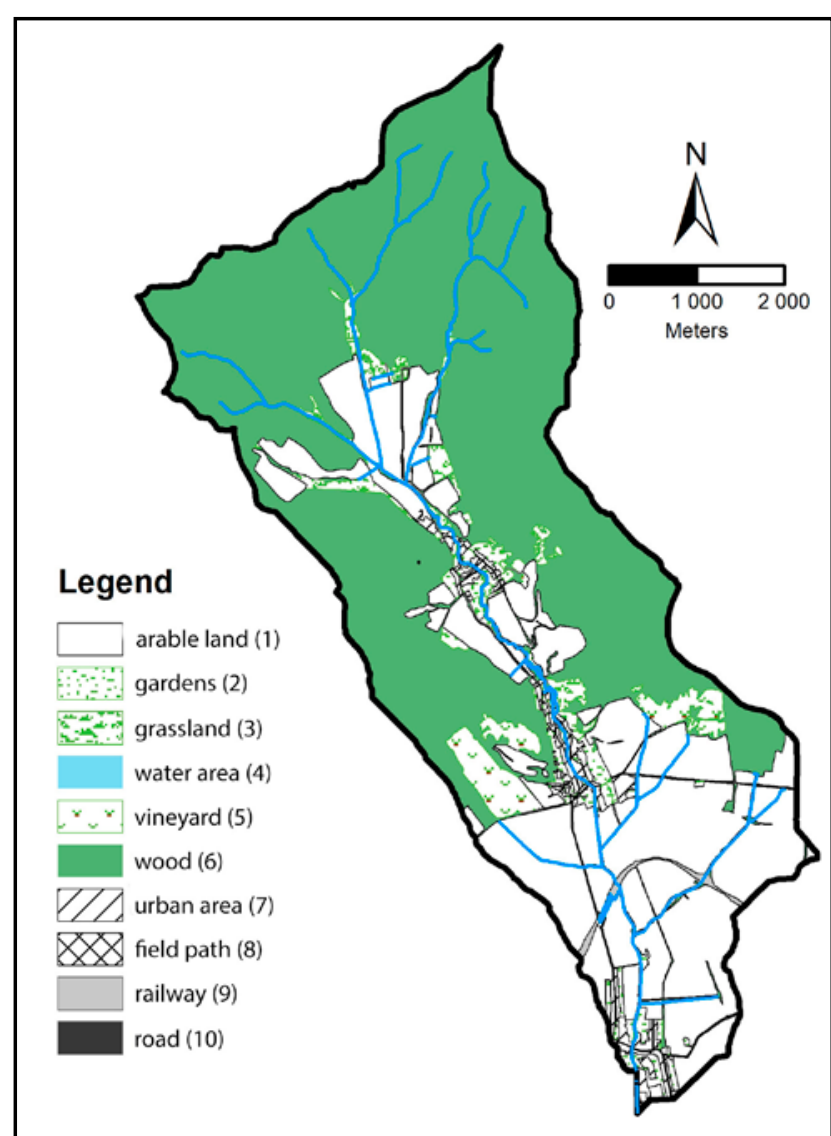

Figure 1 Present landscape structure of the Drevenica subcatchment

Obrázok 1 Súčasná krajinná štruktúra čiastkového povodia Drevenice

(1) orná pôda, (2) záhrady, (3) trávne porasty, (4) vodné plochy, (5) vinice, (6) lesné porasty, (7) zastavaná plocha, (8) polné cesty, (9) železnice, (10) cesty

The daily precipitation totals for the period from 01. 01 . 1981 to 31.12. 1994 from automatic precipitation measuring station in Jelenec (neighbouring village) had been provided by the Slovak Hydrometeorological Institute (SHMU) in Bratislava. Runoff volume calculations were made for the two highest actual rainfall events $-72 \mathrm{~mm}$ of 3 October 1993 and $42.8 \mathrm{~mm}$ of 1 September 1994. We assumed that the rainfalls were the same throughout the whole area.

The simulation of runoff was made for 4 scenarios:

1. CLU - current land use.

2. FR (Forest) - landscape covered by forests, except the maintaining the current urban area, gardens, paved and unpaved roads.

3. PG (Permanent Grassland) - landscape covered by permanent grassland, except the maintaining the existing forest area, urban area, gardens, paved and unpaved roads,

4. AL (Arable Land) - landscape covered by arable land, except the maintaining the current forest area, urban area, gardens, paved and unpaved roads.

Areas of land use at different scenarios in the Drevenica subcatchment are located in Tab. 1

The calculation and visualization of the volume of direct runoff were made in ArcGIS 9.1 environment. The Curve number (CN) method was chosen and we proceeded according to the methodology developed by V. T. Chow (1964), adjusted to the conditions of Slovakia by Antal (1985, 1999). Depth of direct runoff from the forest area was calculated according to the data of condition, age and species composition of the forest from forest management plan provided by the National Forest Centre in Zvolen. In the urban area $\mathrm{CN}$ value was calculated for the built-up area and the gardens separately. In the case of arable land, we took CN numbers for fallow land, because the chosen rainfall events occurred outside the main growing season of agricultural crops, and also we did not have data about crops grown on arable land on the area of interest. The total precipitation for the 5 days before the rainfall event of $72 \mathrm{~mm}$ was $23 \mathrm{~mm}$, therefore we calculated with CN the value for antecedent moisture condition class (AMC) II. In the second case, runoff volume calculation was made for AMC II and AMC III (precipitation in 5 days was $53.5 \mathrm{~mm}$ ). As

Table 1 Area of land under different forms of land use in ha in the Drevenica subcatchment

\begin{tabular}{|c|c|c|c|c|}
\hline \multirow[t]{2}{*}{ Land use (1) } & \multicolumn{4}{|c|}{ Area in ha (2) } \\
\hline & CLU & FR & PG & $A L$ \\
\hline Forest (3) & $2,199.271$ & $3,452.234$ & $2,199.271$ & $2,199.271$ \\
\hline Permanent grassland (4) & 53.268 & - & $1,252.963$ & - \\
\hline Pasture (5) & 36.541 & - & - & - \\
\hline Arable land (6) & $1,067.098$ & - & - & $1,252.963$ \\
\hline Paved roads (7) & 27.745 & 27.745 & 27.745 & 27.745 \\
\hline Unpaved roads (8) & 0.747 & 0.747 & 0.747 & 0.747 \\
\hline Vineyard (9) & 96.056 & - & - & - \\
\hline Water area (10) & 0.218 & 0.218 & 0.218 & 0.218 \\
\hline Urban area (11) & 74.383 & 74.383 & 74.383 & 74.383 \\
\hline Grassland (12) & 80.496 & 80.496 & 80.496 & 80.496 \\
\hline
\end{tabular}

Tabulka 1 Výmera rôznych foriem využívania pôdy $\mathrm{v}$ ha $\mathrm{v}$ čiastkovom povodí Drevenice

(1) formy využivania pôdy, (2) plocha v ha, (3) lesné porasty, (4) trvalo trávnaté porasty, (5) pasienky, (6) orná pôda, (7) spevnené cesty, (8) nespevnené cesty, (9) vinice, (10) vodné plochy, (11) zastavaná plocha, (12) trávnaté porasty 
we did not have accurate data on agricultural crops grown in the area of interest and boundaries of AMC are given for growing and non-growing period differently, we made calculations for both possibilities.

The next step was the calculation of potential maximum retention, direct runoff depth and volume in terms of relationships (1), (2) (Chow, 1964) and (3) at the level of each raster cell $10 \times 10 \mathrm{~m}$ (Muchová, Vanek et al., 2009). The total runoff volume for the subcatchment was reached with gradual culmination (Flow accumulation, Spatial Analyst Tools) of individual cells based on derived flow direction.

$$
\begin{gathered}
S=25.4 \cdot\left(\frac{1000}{C N}-10\right) \\
H=\frac{(P-0.2 \cdot S)^{2}}{P+0.8 \cdot S} \\
V=\frac{Q}{1000} \cdot S_{\text {cell }}
\end{gathered}
$$

where:

$S$ - potential maximum retention $(\mathrm{mm})$

$\mathrm{CN}$ - the Curve Number value for given area

$H$ - the direct runoff depth $(\mathrm{mm})$

$P$ - the total storm rainfall $(\mathrm{mm})$

$V$ - the direct runoff volume for given cell

$S_{\text {cell }}$ - the cell's area $\left(\mathrm{m}^{2}\right)$

Peak discharge in the chosen profiles for rainfall event $72 \mathrm{~mm}$ was calculated in the following steps (NRCS method, In Muchová a Konc, 2010):

1. Travel time for sheet flow in the subcatchment was calculated as a function of representative $\mathrm{CN}$ value for given part of the area, slope and slope length of sheet flow, which was determined by the surface curvature.

2. Travel time for shallow concentrated flow was determined as a function of concentrated flow length and runoff velocity for unpaved surface - natural bed of the watercourse (Drevenica).

3. Travel time for open channel flow was defined in a similar way, i.e. as a function of channel flow length and runoff velocity, but the actual velocity rate was determined as function of the bed roughness, hydraulic radius and bed slope.

4. The maximum sum of the travel time for sheet flow, travel time for shallow concentrated flow and travel time for open channel flow gave us the time of concentration $\left(\tau_{\max }\right)$.

5. Unit peak discharge $\left(q_{u, \max }\right)$ was calculated by computed $I_{a} / P$ ratio $\left(I_{a}\right.$ as initial abstraction $\left.=0.2 \times S\right)$ and nomogram for NRCS (SCS) type II rainfall distribution, i.e. by derived relations (Cronshey, McCuen et al., 1986).

$$
q_{u, \max }=10^{C_{0}+C_{1} \cdot \log \tau_{\max }+C_{2} \cdot\left[\log \left(\tau_{\max }\right)\right]^{2}}, \mathrm{csm} \cdot \mathrm{in}^{-1}
$$

where:

$C_{0^{\prime}} C_{1}$ and $C_{2}$ - the regression coefficients depending on $I_{a} / P$ ratio
Table 2 Regression coefficients for various $I_{a} / P$

\begin{tabular}{|c||c|c|c|}
\hline$I_{a} / P$ & $C_{0}$ & $C_{1}$ & $C_{2}$ \\
\hline \hline 0.10 & 2.55323 & -0.61521 & -0.16403 \\
\hline 0.30 & 2.46532 & -0.62257 & -0.11657 \\
\hline 0.35 & 2.41896 & -0.61594 & -0.08820 \\
\hline 0.40 & 2.36409 & -0.59857 & -0.05621 \\
\hline 0.45 & 2.29238 & -0.57005 & -0.02281 \\
\hline 0.50 & 2.20282 & -0.51599 & -0.01259 \\
\hline
\end{tabular}

Tabulka 2 Regresný koeficient pre rôzne $I_{a} / P$

6. Peak discharge $\left(Q_{\max }\right)$ as a function of unit peak discharge, direct runoff, pond and swamp (water area) adjustment factor $(f)$ and catchment area $\left(S_{p}\right)$ is defined followingly:

$$
Q_{\max }=0.000431 \cdot q_{u, \max } \cdot H \cdot S_{p} \cdot f, \mathrm{~m}^{3} \cdot \mathrm{s}^{-1}
$$

The relations (4) and (5) for the unit peak discharge and peak discharge calculations were adjusted for the conditions of Slovakia e.g. by Janecek (2007).

Based on typical cross-section of riverbed and calculations of stage discharge curve in these profiles from project documentation of the Drevenica (implementation of stream regulation took place in 1960s) provided by the Slovak Water Management Enterprise (Slovenský vodohospodársky podnik), individual hydraulic parameters were determined (i.e. hydraulic radius, wetted perimeter, cross sectional flow area, roughness - table 4). Based on the obtained hydraulic parameters, the flow capacity of the river bed was determined, and by comparing the peak discharge with the riverbed capacity (where the calculated peak discharge reached the riverbed capacity), it was possible to identify the predicted point of outflow from the riverbed for rainfall event. On the raster line showing the peak discharge, the cells with the same and higher discharge than the flow capacity of the channel were found. The representative cross-section of the riverbed was selected in order to simplify the calculation of the travel time for open channel flow.

\section{Results and discussion}

The impact of land use and crop structure changes on the runoff depth and volume from catchments is documented in several works of Slovak and foreign authors (e.g. Kostka a Holko, 2006; Hlavčová et al., 2005; Hlavčová, Szolgay and Kohnová, 2010; Harssema, 2005; Liu et al., 2006). It is proved that in the case of a completely wooded area the runoff volume is the lowest. This happened in our case, too.

In the comparison of the runoff volume (Table 3 ) for rainfall $72 \mathrm{~mm}$ with $\mathrm{AMC}$ II and runoff volume for rainfall $42.8 \mathrm{~mm}$ with AMC III, one can see that although the values are lower at lower rainfall, they are also essentially comparable to volume values for rainfall $72 \mathrm{~mm}$, and thus damage caused by flood could be in comparable character and range.

The highest volumes of runoff were in all rainfall events for scenario arable land and the lowest in forest scenario. On one hand, it is caused by the curve number values, which are 
Table 3

Direct runoff in $\mathrm{m}^{3}$ from the Drevenica catchment

\begin{tabular}{|l||c|c|c|c|}
\hline \multicolumn{1}{|c||}{} & \multicolumn{4}{c|}{ Runoff volume in $\mathbf{~}^{\mathbf{3}}$ (1) } \\
\cline { 2 - 5 } & CLU & FR & PG & AL \\
\hline \hline Rainfall (2) $72 \mathrm{~mm}$, AMC II & $841,919.116$ & $474,081.206$ & $491,934.089$ & $893,235.254$ \\
\hline Rainfall 42.8 mm, AMC II & $284,216.407$ & $107,998.268$ & $111,419.178$ & $311,807.987$ \\
\hline Rainfall 42.8 mm, AMC III & $668,314.139$ & $429,606.207$ & $443,427.902$ & $699,555.243$ \\
\hline
\end{tabular}

Tabulka 3 Priamy odtok $z$ čiastkového povodia Drevenica $v \mathrm{~m}^{3}$

(1) objem odtoku, (2) zrážka

set by methodology and on the other hand by the land type area and land use.

The calculated discharge flow in the riverbed of the Drevenica at the confluence with the Jelenský creek was $69.84 \mathrm{~m}^{3} \cdot \mathrm{s}^{-1}$. According to the data from the project documentation of the Drevenica stream, its riverbed transferred maximum $33.75 \mathrm{~m}^{3} \cdot \mathrm{s}^{-1}$. The location of the outflow point should be above the village Kostolany pod Tríbečom, where several small streams are confluenced. The spill of water on arable land and meadows would cause a reduction of peak discharge in the closer profile of the subcatchment (Figure 3). According to the data

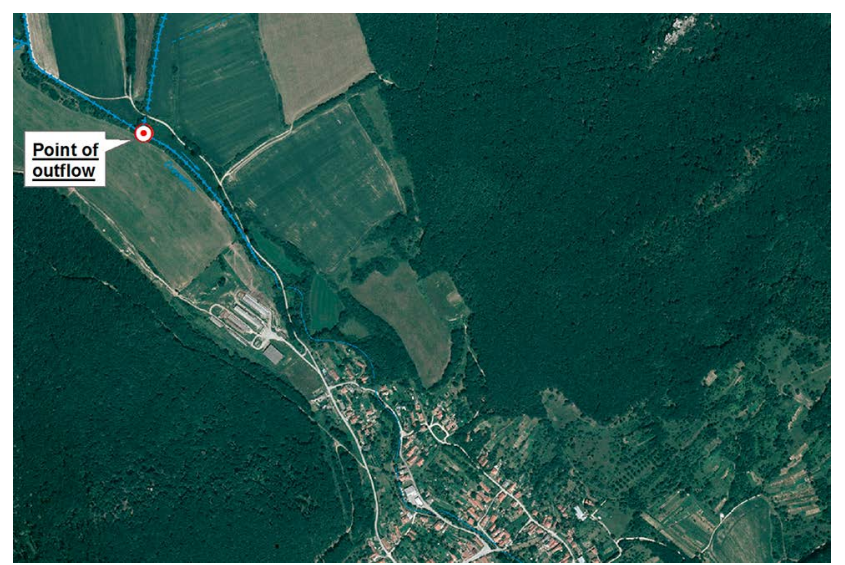

Figure 2 Map with the probable point of outflow of the Drevenica stream (@EUROSENCE)

Obrázok 2 Mapa s pravdepodobným miestom vyliatia potoka Drevenica

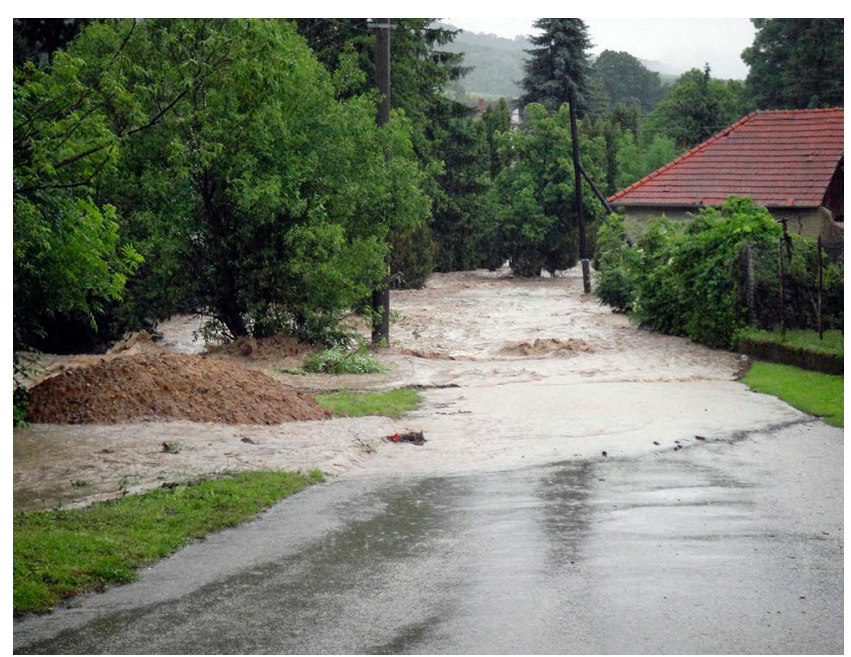

from the meteorological station in Malanta managed by the Department of Biometeorology and Hydrology (at a distance of $12 \mathrm{~km}$ from the area of interest), the maximum rainfall was in June 1, 2010 with $50.6 \mathrm{~mm}$, and 2 days prior to this rainfall, the total rainfall was $40.6 \mathrm{~mm}$ (for a whole

Table 4 Hydraulic parameters for the Drevenica subcatchment

\begin{tabular}{|c|c|}
\hline Parameters (1) & Value (2) \\
\hline Area of the subcatchment in $\mathrm{km}^{2}(3)$ & 36.36 \\
\hline Travel time for sheet flow in $\mathrm{h}(4)$ & 0.29 \\
\hline Travel time for shallow concentrated flow in $\mathrm{h}$ (5) & 0.54 \\
\hline Riverbed roughness ${ }^{\prime \prime} n^{\prime \prime}(6)$ & 0.031 \\
\hline Hydraulic radius (7) & 1.22 \\
\hline Travel time for open channel flow in $\mathrm{h}(8)$ & 1.05 \\
\hline Time of concentration in h (9) & 1.88 \\
\hline Unit peak discharge $q_{u, \max }(10)$ & 192.50 \\
\hline Runoff depth $H$ in mm (11) & 23.20 \\
\hline Peak discharge $Q_{\max }$ in $\mathrm{m}^{3} . \mathrm{s}^{-1}(12)$ & 69.84 \\
\hline
\end{tabular}

Tabulka 4 Hydraulické parametre pre čiastkové povodie Drevenice

(1) parametre, (2) hodnota, (3) výmera čiastkového povodia, (4) doba dobehu plošného odtoku $v h$, (5) doba dobehu plytkého sústredeného odtoku $h$, (6) drsnost koryta, (7) hydraulický radius, (8) postupová doba odtoku v otvorenom koryte, (9) doba koncentrácie odtoku, (10) jednotkový kulminačný prietok, (11) híbka odtoku, (12) kulminačný prietok

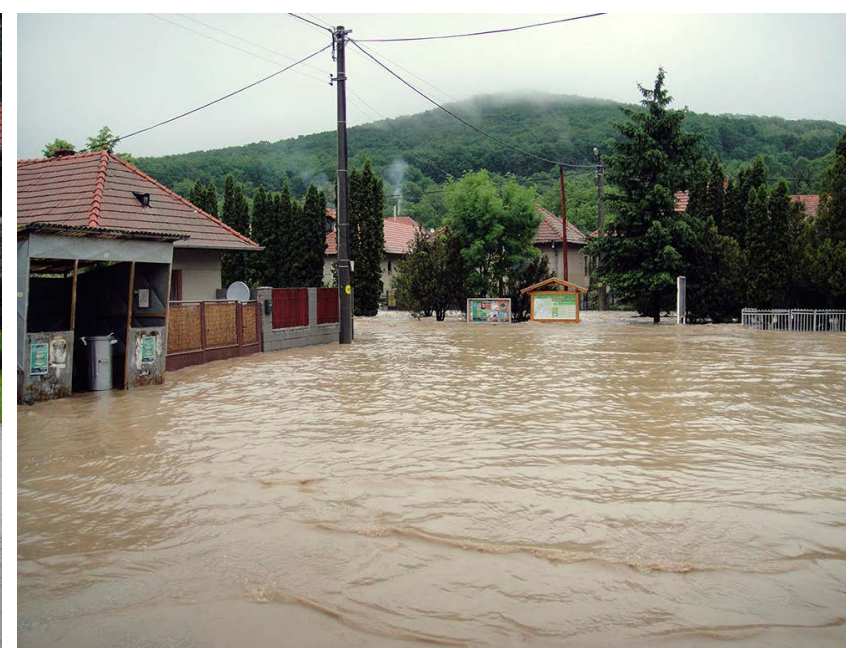

Figure 3 The flood situation in northern (left) and central part (right) of the village Kostolany pod Tríbečom (May, 2010)

Obrázok 3 Povodňová situácia v severnej (vlavo) a centrálnej (vpravo) časti obce Kostolany pod Tríbečom (máj 2010) 
month of May, it was $182.2 \mathrm{~mm}$ ). Therefore, we can use comparison of our calculation with the data from the earlier period and situation in the year 2010. In the year 2010, the flood situation was similar to our, when the point of outflow was above the village.

\section{Conclusion}

The simulation of runoff from the area of interest, as well as calculation of the time of concentration and peak discharge were performed in ArcGIS 9.1 environment. To determine the runoff volume, $\mathrm{CN}$ method was selected, adjusted to the conditions of Slovakia. Time of concentration and peak discharge were calculated by NRCS method.

Comparing runoff volume at 4 different land use scenarios, we achieved the lowest flow in the area completely covered with forests, and the highest runoff in the territory covered by arable land. In the case of properly selected crop rotation, the direct runoff depth would be lower than the one calculated by us (i.e. for a fallow alternative). The predicted catchment saturation by the previous rainfall caused a comparable runoff volume from the solved area, although the difference between the compared rainfalls was nearly $30 \mathrm{~mm}$.

The peak discharge in the solved area (final profile of the subcatchment) was $69.84 \mathrm{m3} . \mathrm{s}^{-1}$ at the time of the concentration, $1.88 \mathrm{~h}$. In this case, the spill of water from the riverbed should occur on arable land above the village Kostolany pod Tríbečom. The floods in May 2010 caused by comparable rainfall shows that our calculations should be correct.

In a similar way, we can proceed with other catchments, where there is no sufficient quantity of the measured characteristics. The advantage of using the model is the choice of several options of land use and different rainfall totals, and thus to establish the probable location of point of outflow water from the riverbed, as well as the time of concentration. This gives the possibility to municipal authorities to be able to respond to the situation caused by extreme rainfalls in time.

\section{Súhrn}

Topografická stavba Slovenska a hustota hydrografickej siete, najmä malých tokov, neumožňuje vykonávat' merania na každom vodnom toku. Z toho dôvodu bolo vytvorených množstvo zrážkovo-odtokových modelov. Nami bolo vybrané čiastkové povodie Drevenice od prameňa po sútok s Jelenským potokom. Zvolená bola SCS-CN metóda s využitím prostredia GIS. Výpočet objemu priameho odtoku bol robený pre 4 scenáre - les, trvalé trávne porasty, orná pôda a súčasné využitie krajiny pre zrážky $72 \mathrm{~mm}$ a 42,6 mm. Kulminačný prietok vodného toku pri súčasnom využití územia sme vyčíslili pomocou NRCS metódy pre zrážku $72 \mathrm{~mm}$. Najvyšší objem odtoku pre všetky vybrané zrážky bol pri scenári orná pôda, najnižší pri lese. Porovnaním prietokovej kapacity koryta toku a kulminačného prietoku sme určili predpokladané miesto vyliatia vody z koryta.

Klúčové slová: priamy odtok, prietok, Drevenica, povodeň, SCS-CN metóda

\section{Acknowledgements}

This paper is a result of project implementation: Center of Excellence for Integrated Watershed Management in the Changing Environmental Conditions, No. ITMS 26220120062; supported by the research and development operational program financed from the ERDF.

We support research activities in the Slovak Republic/Project is co-financed from EU sources.

This study was further supported by projects APVV 0139-10, VEGA 1/0949/11, VEGA 1/0656/12, VEGA 2/0040/12, KEGA 037SPU-4/2011 and KEGA 003SPU-4/2012.

\section{References}

ANTAL, J. 1985. Soil conservation and (forestry) meliorations. II. Manual. Nitra : SUA. 208 p.

ANTAL, J. 1999. Agrohydrology. 2. supplemented edition. Nitra : SUA. 168 p. ISBN 80-7137-610-8.

CRONSHEY, R. - MCCUEN, R. H. et al. 1986. Urban Hydrology for Small Watersheds. Technical Release 55 (TR-55). USDA, Natural Resources Conservation Service. $160 \mathrm{p}$.

HARSSEMA, S. 2005. A GIS based Surface Runoff Modelling and Analysis of Contributing Factors; A Cas Study of the Nam Chun Watershed Thailand. ITC Enschede. $99 \mathrm{p}$.

HLAVČOVÁ, K. - SZOLGAY, J. - KOHNOVÁ, S. - PAPÁNKOVÁ, Z. HORVÁT, O. 2005. On the Possibility of Assessment of land use change impact on runoff with a hydrological model with distributed parameters. In: Meteorological Journal, 2005, no. 8, pp. 74-81.

HLAVČOVÁ, K. - SZOLGAY, J. - KOHNOVÁ, S. 2010. Assessment of the land use impact on the maximum design discharge. In: Flood 2010: causes, course and experience. Bratislava : VUVH. ISBN 978-80-8962-71-3.

CHOW, V. T. 1964. Handbook of Applied Hydrology. New York : McGraw Hill.

JANEČEK, M. et al. 2007. Protecting of agricultural land from erosion. Praha: Research Institue of Soil and Water Conservtion, 2007. 76 p. ISBN 978-80-254-0973-2

JURÍK, L. - PIERZGALSKI, E. - HUBAČíKOVÁ, V. 2011. Water works in the landscape. Small water reservoirs. Nitra : SUA, 168 p. ISBN 978-80-552-0623-3.

KOSTKA, Z. - HOLKO, L. 2006. Role of forest in hydrological cycle-forest and runoff. In: Meteorological Journal, 2006, no. 9, p. 125-133. LIU, Y. B. et al. 2006. Predicting storm runoff from different land-use classes using a geographical information system-based distributed model. Hydrol. Process. 2006, no. 20, pp. 533-548.

MUCHOVÁ, Z. - VANEK, J. et al. 2009. Methodological standards for the design of land consolidation. Nitra : SUA, 2009. suppl., p. 397, ISBN 978-8-552-0267-9.

MUCHOVÁ, Z. - KONC, L.. 2010. Land consolidation: the procedures, approaches and explanations. Nitra: SUA, 2010. 222 p. ISBN 978-80-552-0426-0.

TUPÝ, J. - ZÁLEŠÁKOVÁ, J. - JURÍK, L. 2011. Recovery of flooded areas. In: The science for population protection, vol. 3, 2011, no. 2, pp. 147-162. ISSN 1803-568X.

\section{Contact address:}

Ing. Karol Šinka, PhD., Slovak University of Agriculture in Nitra, Faculty of Horticulture and Landscape Engineering, Hospodárska 7, 94976 Nitra, Slovakia, 표 +421 3764152 34, e-mail: karol.sinka@uniag.sk 